\title{
A ruptured 17 week right cornual gestation after failed termination of pregnancy
}

\author{
Başarısız gebelik tahliyesi sonrası 17. gebelik haftasında rüptüre olan sağ kornual \\ ektopik gebelik
}

\author{
Sümeyra Nergiz Avcıoğlu, Sündüz Özlem Altınkaya, Emre Zafer, Selda Demircan Sezer, \\ Hasan Yüksel
}

Adnan Menderes Üniversitesi, Kadın Hastalıkları ve Doğum AD, Aydın

\begin{abstract}
Cornual (interstitial) pregnancy is one of most hazardous type of ectopic pregnancy. It constitutes $2-4 \%$ of all ectopic gestations and may represent clinically stable until late gestational periods. In this case report, A ruptured right cornual gestation at the 17th week of gestation, following failed termination of pregnancy was presented. A 29-year-old woman, G2P1, presented to the emergency department with acute abdominal pain lasting for 12 hours. Her blood pressure was $50 / 20 \mathrm{mmHg}$, heart rate was $110 \mathrm{bpm}$. Emergent laparatomy was performed. In laparatomy, hemoperitoneum was observed. Intraoperatively, we encountered a right lateral wall ruptured uterus with a 17 week old fetus in the peritoneal cavity, suggesting a right cornual ectopic pregnancy which ended up as a catastrophic event. A cornual resection and repair was done successfully.
\end{abstract}

Pam Med J 2015;8(3):255-258

Key words: Cornual pregnancy, Ectopic pregnancy, uterine rupture.

\section{Özet}

Kornual (interstisyel) gebelik oldukça hayati riski olan ektopik gebelik çeşitlerinden biridir. Tüm ektopik gebeliklerin \%2-4'ünü oluşturmaktadır. İleri gebelik haftalarına kadar klinik olarak sessiz seyredebilir. Burada, başarısız bir gebelik terminasyonundan sonra, 17.gestasyonel haftada rüptüre olan bir sağ kornual gebelik olgusu sunulmuştur. Yirmi dokuz yaşında gravida 2, para 1, abortus 0 olan hasta, on iki saattir devam eden şiddetli karın ağrısı şikayetiyle acil servise başvurmuştur. Hastanın kan basıncı 50/20 mmhG, nabız 110/dak. idi. Acil koşullarda laparatomy uygulandı. Batın içerisinde yoğun hemorajik vasıfta mai izlendi. Lapratomi esnasında, abdominal kavitede, uterus sağ üst yan duvardan rüptüre olmuş 17 hafta gebelik haftasıyla uyumlu fetus gözlendi. Katastrofik şekilde sonuçlanan bu klinik tablo rüptüre sağ kornual gebelik ile uyumlu idi. Sağ kornual rezeksiyon ve onarım başarılı şekilde uygulandı.

Pam Tıp Derg 2015;8(3):255-258

Anahtar sözcükler: Ektopik gebelik, kornual gebelik, uterin rüptür.

\section{Introduction}

A cornual (interstitial) pregnancy is one of the most hazardous types of ectopic gestations. It was observed 1 in 2500-5000 live births and they have a mortality rate of $2.0-2.5 \%$. The mortality rate is 6-7 times higher than that in ectopic pregnancies [1]. Although the majority of ectopic pregnancies implant in the fallopian tube, in 'interstitial gestation'; implantation occurs in the portion of the fallopian tube that transvers the uterine wall [2]. Although most of clinicians think that ectopic pregnancies occur outside of the uterus [3] this case is important in underscoring the fact that there are variants of ectopic pregnancies that exist within the uterus. Here, a ruptured 17 week right interstitial pregnancy presenting after failed dilation and aspiration in an outpatient clinic is discussed.

\section{Case Presentation}

A 29-year-old woman, G2P1, presented to the emergency department with acute

Sümeyra Nergiz Avcıoğlu

Yazışma Adresi: Adnan Menderes Üniversitesi, Kadın Hastalıkları ve Doğum AD, Aydın

e-mail: sumeyranergiz80@gmail.com 
abdominal pain lasting for 12 hours. The pain was intermittent, sharp and non-radiating in the epigastric region. The patient suffered from extremely severe fever, nausea, vomiting, diarrhea, pain in last two hours. Medical history revealed an 'aspiration abortion' performed in the 6th week of gestation. After termination procedure, she experienced vaginal spotting, but this resolved in 3 days. A gynecologist in an outpatient clinic evaluated her and determined a gestational sac in the uterine cavity. So she decided to continue gestation and ultrasonographic controls were performed by the same clinician. Even a second trimester Trisomy 21 risk evaluation test was performed. High level of alpha-fetoprotein was determined in maternal blood and examination of spine and central nervous system by detailed ultrasonography was recommended.

In our evaluation, the pregnancy age was 17 weeks and 4 days. On physical examination, the patient was in acute distress. Her blood pressure was $50 / 20 \mathrm{mmHg}$ heart rate was 110 bpm. Her abdominal examination was remarkable for severe tenderness to palpation in the lower quadrants bilaterally with rebound or guarding. On pelvic examination, the ectopic pregnancy appreciated abnormal vaginal spotting. The bimanual examination elicited mild tenderness and suggestion of right adnexal mass. Pertinent laboratory testing revealed: haemoglobin of $10 \mathrm{~g} / \mathrm{L}(120-160)$, Hct (Hematocrit.) 28.3\% (36.0-46.0) and beta-HCG (human chorionic gonadotropin) of $30416 \mathrm{mIU} /$ $\mathrm{mL}$. Bedside transvaginal and transabdominal ultrasonography was performed and a ruptured 17 week pregnancy was identified high in abdominal cavity. Abdominal cavity was full of free fluid. An empty uterine cavity was determined (Fig1a).The endo-myometrial mantle or EMM (the distance from the outer part of the gestational sac to the uterine wall) was found to be $5.6 \mathrm{~mm}$ (Fig 1b).

Emergent laparotomy was performed. In laparotomy, hemoperitoneum was observed. Intraoperatively, we encountered ruptured uterus at right lateral wall with a 17 week old fetus in the peritoneal cavity, which suggested a right cornual ectopic pregnancy ended catastrophically (Fig 2). A cornual resection and repair was done successfully.
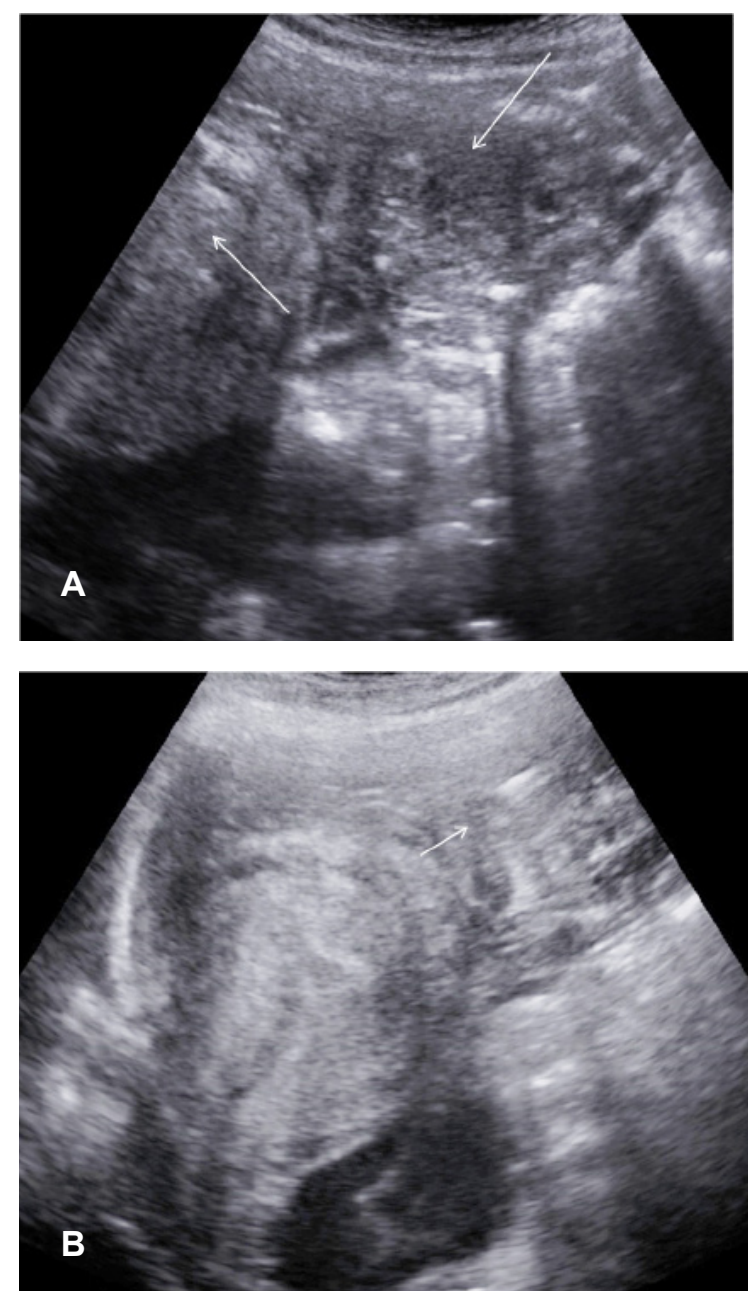

Figure 1. A ruptured 17 weeked pregnancy was identified in abdominal cavity. Abdominal cavity was full of free fluid. An empty uterine cavity was determined (A). The endo-myometrial mantle or EMM (the distance from the outer part of the gestational sac to the uterine wall) was found to be $5.6 \mathrm{~mm}(\mathbf{B})$.

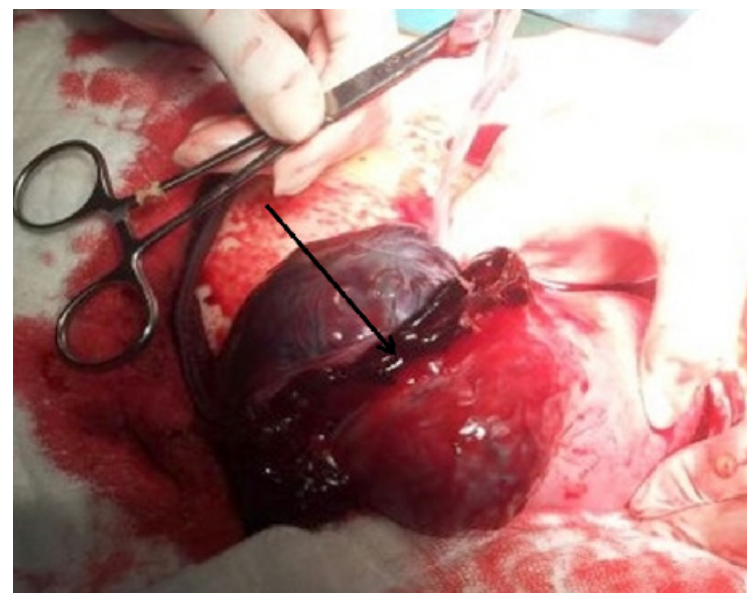

Figure 2. A right lateral wall ruptured uterus with a 17 week old fetus in the peritoneal cavity, which suggested a right cornual ectopic pregnancy which had ended up as a catastrophic event. 


\section{Discussion}

Ectopic pregnancy occurs in approximately $1 \%$ of all pregnancies [4]. It constitutes $2-4 \%$ of all ectopic gestations and may be clinically stable until late gestational periods. [5]. Risk factors for interstitial ectopic pregnancies are similar to those for other ectopic pregnancies, that is, history of sexually transmitted infections or pelvic inflammatory disease, previous ectopic pregnancy and in vitro fertilization [4]. A history of ipsilateral salpingectomy is a risk factor specific for interstitial ectopic pregnancy [1]. In our case, only relaps of pelvic inflammatory disease was determined as a risk factor.

The typical symptoms include abdominal pain and vaginal bleeding. Hemorrhagic shock is found in almost a quarter of the patients. This explains the relatively high mortality rate of cornual pregnancies [6]. An early diagnosis is important and today, it is facilitated by the use of ultrasonography and the quantitative HCG assay. The USG criteria for making a diagnosis include: 1- An empty uterine cavity 2- A gestational sac which is separate from the uterine cavity 3-A myometrial thickness of less than $5 \mathrm{~mm}$ around the gestational sac, typically the interstitial line sign; an echogenic line from the endometrial cavity to the corner which is next to the gestational mass [7]. Similiar ultrasonographic findings were determined in the present case. But this form of ectopic pregnancy can confound the most astute physician and it may not be feasible to differentiate intrauterine and intestitial gestation especially in early gestational periods by ultrasonography [8]. Selma et al. [9] reported that ultrasonographic diagnosis could be performed in $65.6 \%$ of cornual gestations. Thus, as many as $43 \%$ of ectopic cases may go missed in the emergency department, leading to delayed treatment, increased morbidity, or even increased mortality [10]. In the present case, clinician could not differentiate right interstitial pregnancy and intrauterine gestation after failed dilatation and aspiration procedure in an outpatient clinic.

The interstitial segment is more expansile and has a richer vascular supply owing to the surrounding myometrium relative to other parts of the adnexa. Thus, an interstitial ectopic may not cause symptoms until late pregnancy [11]. Rupture can be haemodynamically devastating because of its rich vascular supply. This part of the fallopian tube is $1-2 \mathrm{~cm}$ in length and $0.7 \mathrm{~cm}$ in width, which is supplied by Sampson's artery, which is connected to both the ovarian and the uterine arteries [12]. Interstitial pregnancies can lead to massive haemorrhage with seven times higher mortality compared to other sites [2]. In the present case, the patient presented with a ruptured right interstitial pregnancy at the17th week of gestation.

In this case, the patient presented with an interstitial pregnancy after a failed elective termination of pregnancy. A failed termination is rare, occurring in $0.07-2 \%$ of cases [13]. Early gestational age ( $<6$ weeks) at the time of the termination is associated with a higher incidence of failure. Proposed reasons for this include the use of more technically challenging equipment (e.g. vacuum aspiration) and failure to identify the intrauterine sac and other fetal parts [14].

The traditional treatment includes a surgical cornual resection. However, cornustomy is recommended in small cornual ectopics ( $<3.5$ $\mathrm{cm}$ diameter) whereas cornual resection is said to be more appropriate for larger cornual ectopics ( $>4 \mathrm{~cm}$ diameter) because of increased myometrial invasion [9]. Sometimes, a hysterectomy has to be done due to the hemorrhage. Currently, a more conservative laparoscopic treatment and even a medical treatment can be accomplished with great success and with less unfavourable effects on the future pregnancies [7]. In the patients with asymptomatic interstitial (cornual) pregnancies, methotrexate has been successfully used. All women with cornual pregnancy presenting with initial hCG values of $<5000 \mathrm{mlU}$ were treated successfully with single-dose methotrexate, but almost all women with an initial hcG of $>5000$ $\mathrm{mIU}$ required two doses according to the Royal College of Obstetricians and Gynecologists, UK [4]. Also methotreaxate local injection was reported to be effective [15]. However, this approach may fail and it may result in a cornual rupture of the pregnancy [5]. A selective uterine artery embolisation has been successfully performed to treat these pregnancies [12]. In present case as patient was clinically in severe acute distress, emergency laparatomy and cornual resection was performed.

In conclusion, clinicians should not forget the presence of interstitial pregnancy which is one of the most hazardous types of ectopic gestations and having high maternal mortality rate. An early termination before 6th week of gestation should be avoided, because of high failure rate. If performed, ultrasonographic imaging of endometrial cavity or serial hcg tests should be evaluated after termination. 
Conflict of Interest: Authors declare they have no conflict of interest.

\section{References}

1. Tulandi T, Al-Jaroudi D. Interstitial pregnancy: results generated from the society of reproductive surgeons registry. Obstet Gynecol 2004;103:47-50.

2. Moawad NS, Mahajan ST, Moniz MH, Taylor SE, Hurd WW. Current diagnosis and treatment of interstitial pregnancy. Am J Obstet Gynecol 2010;202:15-29.

3. Doane B, Perera P. Emergency Ultrasound identification of a cornual ectopic pregnancy. West J Emerg Med 2012;13:315.

4. Farquhar CM. Ectopic pregnancy. Lancet 2005;366:583-591.

5. Rheinboldt M, Ibrahim S. Atypical presentation of a large interstitial pregnancy Emerg Radiol 2013;20:251254.

6. Soriano D, Viscus D, Mashiach R, Schiff E, Seidman D, Goldenberg M. Laparoscopic treatment of corneal pregnancy: a series of 20 consecutive cases. J Reprod Immunol 2008;90:839-843.

7. Faraj R, Steel M. Management of cornual (interstitial) pregnancy. RCOG 2007;9:249-255.
8. Chan L, Fok W, Yeun P. Pitfalls in the diagnosis of interstitial pregnancy. Acta Obstet Gynecol Scand 2003;82:867-870.

9. Selma N, Hamontri S, Chua I, Chern B, Siow A. Laparoscopic management of 53 cases of cornual ectopic pregnancy. Fertil Steril 2009;92:448-452.

10. Abbott JT, Emmans LS, Lowenstien SR. Ectopic pregnancy: ten common pitfalls in diagnosis. Am J Emerg Med 1990;8:515-522.

11. Gaber-Patel K, Smith MD. Thirteen-week cornual ectopic pregnancy. Am J Emerg Med 2009;27:900. e1-2.

12. Surekha $S \mathrm{M}$, Chamaraja $\mathrm{T}$, Nabakishore $\mathrm{SN}, \mathrm{Bi}-$ molchandra SN, Neeraja T S. A Ruptured left cornual pregnancy: A case report. J Clin and Diag Res 2013;7:1455-1456.

13. Egan DJ, Li M, Lewiss ER. Interstitial ectopic pregnancy presenting after failed termination of pregnancy. Emerg Med Australas 2012;24:573-576.

14. Tristan SB, Gilliam M. First trimester surgical abortion. Clin Obstet Gynecol 2009;52:151-159.

15. Al-Kharusi L, Gowri V, Al-Sukaiti R, Al-Ghafri W, Rao $\mathrm{K}$. Submyomatous cornual pregnancy managed surgically after failed medical management. Sultan Qaboos Univ Med J 2011;11:399-402. 